\title{
Impact of Firm Specific Factors on Profitability of Firms in Food Sector
}

\author{
Nousheen Tariq Bhutta ${ }^{1 *}$, Arshad Hasan ${ }^{2}$ \\ ${ }^{1}$ Faculty of Management Sciences, International Islamic University, Islamabad, Pakistan \\ ${ }^{2}$ Faculty of Management Sciences, Mohammad Ali Jinnah University, Islamabad, Pakistan \\ Email: *imaantariq@gmail.com, aarshad.hasan@gmail.com
}

Received January 20, 2013; revised March 10, 2013; accepted March 25, 2013

Copyright (C) 2013 Nousheen Tariq Bhutta, Arshad Hasan. This is an open access article distributed under the Creative Commons Attribution License, which permits unrestricted use, distribution, and reproduction in any medium, provided the original work is properly cited.

\begin{abstract}
The aim of this study is to examine the impact of firm specific and macroeconomic factors on profitability of food sector in Pakistan. This study explores the impact of firm specific factors on profitability of companies listed in food sector of Karachi stock market in the presence of food inflation by employing multivariate regression analysis in common effect setting for the period of 2002-2006. The firm specific factors include debt to equity, tangibility, growth and size and macroeconomic factor include food inflation. Findings of study reveal the presence of significant negative relationship between size and profitability. However, tangibility, growth of the firm and food inflation are found insignificantly positively related to profitability. Similarly, an insignificant negative relationship is observed between debt to equity ratio of firm and its profitability. Empirical results provide evidence that the profitability of food sector is shaped by firm specific factors and not macroeconomic variables. One important limitation of study is that it only considers one macroeconomic factor i.e. food inflation. In future studies more macroeconomic factors will be explored to examine their impact on profitability of food sector firms. However, this study still provides significant insight about dynamics of profitability in food sector and helps in making optimal decisions of resource allocation in food sector of Pakistani equity market.
\end{abstract}

Keywords: Profitability; Firm Specific Factors; Macroeconomic Factor; Food Sector

\section{Introduction}

Profitability plays an important role in the structure and development of firm because it measures the performance and success of a firm. It also enhances the reputation of a firm. Maximizing the profits of firm is one of the main objectives of managers. The profitability of a firm is thus a key concern, as is the ability to better withstand negative shocks and contribute to the stability of the system. Profitability also maximizes stakeholder value and investor value. Profitability is vitally important to corporate performance, especially in competition environments. The majority of studies on profitability, such as [1-5] use linear models to estimate the effects of diverse factors which may be significant in amplification of profits. First, the literature predominantly considers determinants of profitability at the firm level with the mixture of variables lacking internal stability, while there is no systematic research of the impact of the macroeco-

${ }^{*}$ Corresponding author. nomic milieu, Second, most of the literature argues that the econometric methodology is not effectively demonstrating some features of profits, which entails that the estimates results may be discriminatory and ambiguous.

This paper shows the impact of firm specific and macroeconomic determinants on profitability of food sector. The group of the firm specific determinants that related profitability involves growth, tangibility, size and debt to equity ratio. The second group of determinants narrates profitability to the macroeconomic milieu within which the food sector operates. For this purpose, we include food inflation among the evocative variable.

This research focuses on firm specific and macroeconomic factors and their effects on profitability for Pakistani food sector firms. The main objectives are:

To establish a relationship among firm specific, macroeconomic factors and profitability over a period of five years (2002-2006) for Pakistani food sector listed on Karachi Stock Exchange.

- To examine the impact of firm specific factors (debt 
to equity ratio, size, tangibility of assets, growth) on profitability of the Pakistani food sector.

- To examine the impact of macroeconomic factor (food inflation) on profitability of the Pakistani food sector.

The paper is organized as follows: Section 1 gives a brief introduction of the background of the study. Section 2 summarizes the related literature. Section 3 gives description of the data and measurement of the variables. Section 4 presents the discussion on specification of model. Section 5 discusses the results from the models used and Section 6 presents the conclusion and future recommendations.

\section{Literature Review}

Many researchers have studied firm specific and macroeconomic determinants from different visions and in different milieus. The following ones are very appealing and helpful for our research.

Studies that deal with internal determinants exploit variables such as size, tangibility, growth and debt to equity ratio. There is a positive significant relationship between size and profitability [6,7]. Leverage is positively correlated with firm size [8-11]. The degree of which various financial, legal and other factors (e.g. corruption) affect profitability is strongly related to firm size [12]. Firm size is positively related to capital $\operatorname{ratios}^{1}[1-3$, $5,13,14]$. The growth opportunities are measured in terms of the fraction of firm's value represented for by assets-in-place; smaller the proportion of firm's value narrated by assets-in-place, the larger are the firm's growth opportunities [15]. The firms with growth opportunities have moderately more development projects, new product lines, acquisitions of other companies and repair and replacement of existing assets [16]. Moreover, growth opportunities and firm size are positively related to profitability [17]. Those firms with low and growth opportunities lean to show high profitability and firms in the middle of the growth opportunities incline to confirm small profitability [18].

The leverage is positively correlated with tangibility and it also emphasizes that leverage should increase with liquidation value [19,20] and in US firms [21,22]. Leverage is negatively related to profitability in both the US and Japan [23]. These findings observed in developing countries $[11,24]$. Leverage is insignificantly positively related to profitability [25]. Profitability has the prime effect on debt over asset ratios [10]. Leverage is positively related to tangibility and is negatively related to profitability because profitability has negative relationship with tangibility. According to pecking order theory

${ }^{1}$ Generally, Central bank and other competent authority measures profitability by return on assets and the return on equity (ROA and ROE, respectively). firms firstly prefer to use internal funds and then doing external financing [26]. This entails that profitable firms will have less extent of leverage [27]. Profitability is negatively correlated to debt to equity (leverage) ratio [28] which was further documented by [26].

The other group of profitability determinants deals with macroeconomic variable that we have used food inflation for this purpose. There is relationship between profitability and inflation [29]. He comments that the effect of inflation on firm profitability depends on whether firms' operating expenses and its wages increase at a more rapidly than inflation. The degree of which inflation affects profitability depends on whether inflation prospect are wholly estimated [30]. Inflation is positively related to profitability [3]. Actual inflation is significantly positive related to profitability [31]. Inflation is red alert at 9 percent threshold inflation level for economic growth [32]. The findings of panel data of Organization for Economic Cooperation and Development (OECD) and Asia-Pacific Economic Cooperation (APEC) countries, which specifies that the inflation has reduced (from double digits to single digit) and it has a significant positive effect on growth for the OECD countries, and less impact on growth for the APEC countries [33]. They further emphasize that the effect of a reduced inflation might only be examined when the world economy is not experiencing a sudden decrease in growth rate due to shocks. If there are no such shocks, a decline in inflation rate can generate significantly higher growth rate. Similarly, inflation has a strong negative impact on growth rate of per capita GDP for OECD countries [34]. By reducing investment and yield growth, inflation diminishes growth [35]. He also reports that by greater capital accumulation and productivity growth, excess large funds are also strongly linked with more growth. At very low inflation rates (less than 2 - 3 percent) inflation is positively correlated to growth. But, they are at high level of inflation shows negatively correlation to growth [36]. Likewise, inflation within the single-digit zone may be favorable, while inflation in the double-digit zone emerges to entail costs in terms of reduced growth [37]. Below than 40 percent of annual inflation rates, there is no relationship between inflation and growth [38]. They exhibit a negative relationship between high inflation (more than 40 percent) and growth.

Cointegration analysis of inflation on economic growth was observed in four South Asian countries (Bangladesh, India, Pakistan and Sri Lanka) and state two appealing points. First, inflation and economic growth are positively related. Second, the sensitivity of growth to changes in inflation rates is smaller than sensitivity of inflation to changes in growth rates [39]. The relationship between output growth and inflation, there is a threshold level of inflation. They not only study the 
relationship of high and low inflation with economic growth but also recommend the threshold inflation level for both industrialized and developing countries [40].

\section{Methodology}

This section of the article discusses the firms and variables included in the study. The distribution patterns of data and applied statistical techniques in investigating the relationship between firm specific, macroeconomic factors and profitability.

\subsection{Data Set \& Sample}

The study is based on data about firm specific factors have been collected [41]. Food inflation prices are taken from Inflation Monitor $[42,43]$. This publication provides useful information on key accounts of the financial statements of all listed firms of KSE. We included all firms of food sector, particularly 12 firms listed at Karachi stock exchange, in our analysis for the period of five years (2002-2006).

\subsection{Variables}

This study identifies key variables that influence profitability of Pakistani food sector. They include dependent and independent variables:

\subsubsection{Dependent Variable}

- Profitability (PF): We take net income ratio which is a measure of profitability of the firm as dependant variable. It is defined as the ratio of net income after taxes divided by total sales.

\subsubsection{Independent Variable}

We take five variables as independent variable:

\section{1) Firm Specific Factors}

- Debt to equity ratio (DTER): According to pecking order theory firms firstly prefer to use internal funds and then doing external financing. This entails that profitable firms will have less extent of leverage [27]. We expect a negative relationship between profitability and debt to equity ratio. We measure debt to equity ratio as total liabilities divided by share holder's equity.

- Tangibility of assets (TG): A firm with large amount of fixed asset tends to be more profitable because of increasing its future assets value. But leverage is positively related to tangibility and is negatively related to profitability because profitability has negative relationship with tangibility [26]. Thus we expect a negative relationship between tangibility of assets and profitability. We measure tangibility of asset (TG) as a ratio of fixed assets divided by total assets. We take total net amount of fixed assets as the numerator. Using total net amount of fixed assets means the cost of fixed assets minus accumulated depreciation.

- Size (SZ): If the size of the firm increases the profitability also increase [6,7]. We measure size (SZ) of the firm by the taking the natural log of the sales as this measure smoothens the variation in the figure over the periods of time. So large size of firm tends to be more profitable. Thus we expect a positive relationship between size and profitability of firm.

- Growth (GT): Better growing firms increase their profitability [17]. If there is an increase in total assets it means it has high growth and it tends to be more profitable. we measure growth (GT) as a percentage increase in total assets Thus we expect positive relationship between growth rate and profitability of firm.

2) Macroeconomic Factor

- Food inflation (FI): It also serves as macroeconomic variable. An increase in food inflation will tend to increase in price of food sector and high prices generate high profit. Inflation is positively related to profitability $[3,31]$. So we expect a positive relationship between food inflation and profitability. Food inflation prices are taken from Inflation Monitor [42,43].

\subsection{Hypotheses Testing}

The objective of this study is to examine the impact of firm or industry specific/macroeconomic factors on profitability of food sector in Pakistan. For this purpose we make two hypotheses:

Hypothesis 1: There is a significant impact of firm specific factors (debt to equity ratio, size, tangibility, growth) on profitability of the Pakistani food sector.

Food Inflation increases the prices of food products that will generate the high profits of food sector companies. Hence

Hypothesis 2: There is a significant impact of macroeconomic factor (food inflation) on profitability of the Pakistani food sector.

We expect that positive relationship of growth, size and food inflation with profitability and negative relationship between debt to equity ratio and tangibility of assets with profitability.

\subsection{Model Specifications}

To find the relationship between independent and dependent variables we employ descriptive statistics, correlation analysis and multivariate regression analysis in common effect setting

$$
\begin{aligned}
\mathrm{PF}_{i t}= & \beta_{0}+\beta_{1}\left(\mathrm{DTER}_{i t}\right)+\beta_{2}\left(\mathrm{TG}_{i t}\right)+\beta_{3}\left(\mathrm{SZ}_{i t}\right) \\
& +\beta_{4}\left(\mathrm{GT}_{i t}\right)+\beta_{5}\left(\mathrm{FI}_{i t}\right)+\varepsilon
\end{aligned}
$$


where:

$\mathrm{PF}_{i t}$ : Profitability of firm $i$ at time $t ; i=1,2, \cdots, 12$ firms.

$t$ : Time $=1,2, \cdots, 5$ years

$\beta_{o}$ : The intercept of equation

DTER: Debt to equity Ratio

TG: Tangibility of Assets

SZ: Size

GT: Growth

FI: Food Inflation

$\varepsilon$ : The error term

\section{Interpretation of Results}

The results of descriptive statistics, correlation and multivariate regression analysis are explained below:

1) Descriptive analysis (Table 1) shows that average loss during period is $13 \%$ and volatility is significantly high. Average growth rate during period is $11 \%$ and volatility is significantly high. On average $50 \%$ of assets are tangible. Debt dependence in industry is $152 \%$ of equity which means that $60 \%$ of assets are financed through debt.

2) Correlation analysis (Table 2) shows profitability is negatively correlated with debt to equity ratio and tangibility and positively related to size, growth and food inflation. Profitability shows significant moderate relation to size and insignificant weak relation to debt to equity ratio, tangibility, growth and food inflation. Debt to equity is negatively correlated with the tangibility and positively correlated with size, growth and food inflation.
Debt to equity ratio shows weak insignificant relation to tangibility, size, growth and food inflation. Tangibility is negatively correlated with size and growth and positively correlated with food inflation, as it shows weak insignificant relation to theses factors. Size is positively correlated with growth and food inflation; it also proves a weak insignificant relation to growth and food inflation. Growth is negatively relationship with food inflation. It further emphasizes weak insignificant relation to food inflation

3) Multivariate regression analysis (Table 3) shows that debt to equity ratio, with coefficient -0.002 is insignificantly related to profitability. It means one unit change in debt to equity ratio decrease the profitability by -0.002 profitability has $t$-value of -0.853 against a $\mathrm{p}$-value of 0.3973 . Thus our hypothesis is rejected by the statically insignificant negative relationship between debt to equity ratio and profitability. The more profitable firm will use less debt. It uses its internal funds. This outcome confirms to pecking order theory.

Tangibility has a negative coefficient and it shows insignificant relationship with profitability. The coefficient value is -0.878 it means one unit change in tangibility of assets will bring negative change in profitability by 0.878 . Tangibility has t-value of -0.8103 against a p-value of 0.4213 . Thus our hypothesis is rejected by the statically insignificant negative relationship between tangibility and profitability. It shows that a firm has less tangibility of assets will be more profitable.

Size has a positive significant relationship to profitability. The coefficient value is 0.347 it means one unit

Table 1. Descriptive statistics.

\begin{tabular}{ccccccc}
\hline & Profitability & Debt/Equity & Tangibility & Size & Growth & Food inflation \\
\hline Mean & -0.131 & 152.3 & 0.49 & 6.63 & 0.11 & 6.14 \\
Median & 0.048 & 100.8 & 0.51 & 6.83 & 0.09 & 6 \\
StdDev & 2.336 & 159.12 & 0.27 & 2.23 & 0.29 & 3.65 \\
Skewness & -3.415 & 2.26 & 0.95 & -0.94 & 2.02 & 0.75 \\
Minimum & -14.5 & 0 & 0.05 & 0.18 & -0.47 & 2.5 \\
\hline
\end{tabular}

Table 2. Correlation matrix.

\begin{tabular}{|c|c|c|c|c|c|c|}
\hline & Profitability & Debt to equity & Tangibility & Size & Growth & Food inflation \\
\hline Profitability & 1 & & & & & \\
\hline Debt to equity & -0.0305 & 1 & & & & \\
\hline Tangibility & -0.1718 & -0.0309 & 1 & & & \\
\hline Size & 0.3566 & 0.1668 & -0.2381 & 1 & & \\
\hline Growth & 0.0254 & 0.0503 & -0.0474 & 0.1667 & 1 & \\
\hline Food inflation & 0.2183 & 0.0915 & 0.0323 & 0.0975 & -0.1164 & 1 \\
\hline
\end{tabular}


Table 3. Multivariate regression analysis.

\begin{tabular}{ccccc}
\hline $\begin{array}{c}\text { Independent } \\
\text { variables }\end{array}$ & Coefficients & S.E. & t-Stat & p-value \\
\hline $\begin{array}{c}\text { Intercept } \\
\begin{array}{c}\text { Debt to equity } \\
\text { ratio }\end{array}\end{array}-^{\text {Tangibility }}$ & -0.530 & 1.2275 & -2.0614 & 0.0441 \\
Size & -0.8780 & 1.0834 & -0.8103 & 0.4212 \\
Growth & 0.3465 & 0.1367 & 2.5343 & 0.0141 \\
Food inflation & -0.0504 & 1.0001 & -0.0503 & 0.9600 \\
& Regression statistics & & \\
Multiple R & & 0.4270 & \\
R square & & 0.1823 & \\
Adj R square & & 0.1066 & \\
Standard error & & 2.2079 & \\
z-value significance & & 0.04 & \\
\hline
\end{tabular}

change in size will lead to increase in profitability by 0.347 . It has t-value of 2.534 against p-value of 0.014 . These findings come according to our hypothesis that there is positive relationship between size and profitability of firm. So it accepts our hypothesis that profitability has positive significant relationship with size.

Growth has a negative coefficient but it is insignificant relationship to profitability. The coefficient value is -0.05 . It means a unit change increase in growth bring a negative change in profitability by 0.05 . It has t-value of -0.050 against a p-value of 0.960 . Thus there is a negative relationship between growth and profitability of firm. But the t-value of -0.050 is value is very small and the p-value is 0.960 , it shows that growth is not a proper explanatory variable of profitability. So it rejects our hypothesis that there is a significant relation between profitability and growth.

Food Inflation has positive coefficient 0.127 but it is insignificant related to profitability. The positive coefficient shows that one unit increase in food inflation will bring positive change of 0.127 . It has t-value of 1.581 against a p-value of 0.120 . It means there is positive relationship between profitability and food inflation but show insignificant relation. On the basis of this, we reject our second hypothesis.

The value of $\mathrm{R}$ square is 0.182 . It means the explained part of our model is $18 \%$ and the residual (un-explained) is about $82 \%$. It shows that our model explains only $18 \%$ of factors that affect profitability of firm. These outcomes also show that only size of firm is a proper explanatory variable of profitability among debt to equity ratio, tangibility of assets, growth and food inflation.

\section{Discussion and Concluding Remarks}

In this paper, we specified an empirical framework to investigate the impact of firm specific and macroeconomic determinants on the profitability of Pakistani Food sector for the period of 2002-2006. Novel features of our study are the simultaneous analysis of the effect of the firm specific and macroeconomic determinants on the profitability of Pakistani Food sector with an appropriate econometric methodology (correlation and Multivariate regression analysis) for the estimation of the model.

We used five explanatory variables to measure their effect on profitability of Pakistani food sector. One of our explanatory variables was statistically significant and other four were statistically insignificant related to profitability. Size of firm is an only explanatory variable that has significant relationship with profitability of firms in food sector. Debt to equity ratio, tangibility of assets, growth and food inflation have insignificant relationship with profitability of firms in food sector. According to these findings here we conclude that debt to equity ratio, tangibility of assets, growth and food inflation are unable to explain profitability in food firms. So our first hypothesis confirms there is significant positive relationship in term of size. But tangibility and growth has positive but insignificant relationship with profitability and debt to equity has negative and insignificant impact on profitability. Our second hypothesis is also rejected due to insignificant relationship between profitability and food inflation.

These findings indicate the large firms are more profitable in Pakistani food sector. Moreover model is significant 5\% level. Results of food industry are overall discouraging with average loss of $13 \%$. But a growth of $11 \%$ is visible which more than average reported inflation during period. Important factors like capital structure, growth, food inflation and tangible assets are not statistically significant and are affecting profits. Size is only critical factor and should be considered in making investment decision.

\section{Practical Implication/Limitation}

Overall, these empirical results provide evidence that the profitability of food sector is shaped by firm specific factors and not macroeconomic variables. Explanatory power of model is weak so a more extensive study is recommended to identify the unique determinants of profits in food sector. This study only examines one macroeconomic factor so in next study impact of other variables should also be captured. Food industry did not perform well during last 5 periods so a study with large data set is also proposed. 


\section{REFERENCES}

[1] B. K. Short, "The Relation between Commercial Bank Profit Rates and Banking Concentration in Canada, Western Europe and Japan," Journal of Banking and Finance, Vol. 3, No. 3, 1979, pp. 209-219.

doi:10.1016/0378-4266(79)90016-5

[2] P. Bourke, "Concentration and Other Determinants of Bank Profitability in Europe, North America and Australia," Journal of Banking and Finance, Vol. 13, No. 1, 1989, pp. 65-79. doi:10.1016/0378-4266(89)90020-4

[3] P. Molyneux and J. Thornton, "Determinants of European Bank Profitability: A Note," Journal of Banking and Finance, Vol. 16, No. 6, 1992, pp. 1173-1178. doi:10.1016/0378-4266(92)90065-8

[4] A. Demirguc-Kunt and H. Huizinga, "Financial Structure and Bank Profitability," World Bank Mimeo, 2000.

[5] J. Goddard, P. Molyneux and J. O. S. Wilson, "The Profitability of European Banks: A Cross-Sectional and Dynamic Panel Analysis," Manchester School, Vol. 72, No. 3, 2004, pp. 363-381. doi:10.1111/j.1467-9957.2004.00397.x

[6] J. D. Akhavein, A. N. Berger and D. B. Humphrey, "The Effects of Megamergers on Efficiency and Prices: Evidence from a Bank Profit Function," Finance and Economic Discussion Series, Vol. 9, Board of Governors of the Federal Reserve System, 1997.

[7] M. Smirlock, "Evidence on the (Non) Relationship between Concentration and Profitability in Banking," Journal of Money, Credit, and Banking, Vol. 17, No. 1, 1985, pp. 69-83. doi:10.2307/1992507

[8] P. Marsh, "The Choice between Equity and Debt: An Empirical Study," Journal of Finance, Vol. 37, No. 1, 1982, pp. 121-144. doi:10.1111/j.1540-6261.1982.tb01099.x

[9] R. Rajan and L. Zingales, "What Do We Know about Capital Structure? Some Evidence from International Data," Journal of Finance, Vol. 50, No. 5, 1995 pp. 14211460. doi:10.1111/j.1540-6261.1995.tb05184.x

[10] W. K. John, "How Firm Characteristics Affect Capital Structure: An International Comparison," Journal of Financial Research, Vol. 22, No. 2, 1999, pp. 161-187.

[11] L. Booth, V. Aivazian, A. Demirguc-Kunt and V. Maksmivoc, "Capital Structures in Developing Countries," Journal of Finance, Vol. 56, No. 1, 2001, pp. 87-130. doi:10.1111/0022-1082.00320

[12] A. Demirguc-Kunt and H. Huizinga, "Determinants of Commercial Bank Interest Margins and Profitability: Some International Evidence," World Bank Economic Review, Vol. 13, No. 2, 1998, pp. 379-408. doi:10.1093/wber/13.2.379

[13] J. A. Haslem, "A Statistical Analysis of the Relative Profitability of Commercial Banks," Journal of Finance, Vol. 23, No. 1, 1968, pp. 167-176. doi:10.1111/j.1540-6261.1968.tb03004.x

[14] J. A. Bikker and H. Hu, "Cyclical Patterns in Profits, Provisioning and Lending of Banks and Procyclicality of the New Basel Capital Requirements," BNL Quarterly Review, Vol. 221, No. 1, 2002, pp. 143-175.
[15] S. C. Myers, "Determinants of Corporate Borrowing," Journal of Financial Economics, Vol. 5, No. 2, 1977, pp. 147-175. doi:10.1016/0304-405X(77)90015-0

[16] S. P. Mason and R. C. Merton, "The Role of Contingent Claims Analysis in Corporate Finance," Recent Advances in Corporate Finance, Holmwood, 1985.

[17] J. Abor, "The Effect of Capital Structure on Profitability: An Empirical Analysis of Listed Firm in Ghana," Journal of Risk Finance, Vol. 6, No. 5, 2005, p. 438. doi:10.1108/15265940510633505

[18] Z. Serrasqueiro, N. Maria and M. Paulo, "The Explanatory Power of Capital Structure Theories: A Panel Data Analysis," Icfai Journal of Applied Finance, Vol. 13, No. 7, 2007, pp. 23-38.

[19] O. Williamson, "Corporate Finance and Corporate Governance," Journal of Finance, Vol. 43, No. 3, 1988, pp. 567-591. doi:10.1111/j.1540-6261.1988.tb04592.x

[20] M. Harris and A. Raviv, "Capital Structure and the Informational Role of Debt," Journal of Finance, Vol. 45, No. 2, 1990, pp. 321-349. doi:10.1111/j.1540-6261.1990.tb03693.x

[21] I. Friend and L. H. P. Larry, "An Empirical Test of the Impact of Managerial Self-Interest on Corporate Capital Structure," Journal of Finance, Vol. 43, No. 2, 1988, pp. 271-281. doi:10.1111/j.1540-6261.1988.tb03938.x

[22] S. Titman and R. Wessels, "The Determinants of Capital Structure Choice," Journal of Finance, Vol. 43, No. 1, 1988, pp. 1-19. doi:10.1111/j.1540-6261.1988.tb02585.x

[23] W. C. Kester, "Capital and Ownership Structure: A Comparison of United States and Japanese Manufacturing Corporation," Financial Management, Vol. 15, No. 1, 1986, pp. 5-16. doi:10.2307/3665273

[24] Y. Wiwattanakantang, "An Empirical Study on the Determinants of the Capital Structure of Thai Firms," $\mathrm{Pa}$ cific-Basin Finance Journal, Vol. 7, No. 3-4, 1999, pp. 371-403. doi:10.1016/S0927-538X(99)00007-4

[25] M. Long and I. Maltiz, "The Investment-Financing Nexus: Some Empirical Evidence," Midland Corporate Finance Journal, Vol. 3, No. 3, 1985, pp. 53-59.

[26] A. Shah and S. Khan, "Determinants of Capital Structure: Evidence from Pakistani Panel Data," International Review of Business Research Papers, Vol. 3, No. 4, 2007 pp. 265-282.

[27] C. M. Stewart and N. S. Majluf, "Corporate Financing and Investment Decisions When Firms Have Information that Investors Do Not Have," Journal of Financial Economics, Vol. 13, No. 2, 1984, pp. 187-221. doi:10.1016/0304-405X(84)90023-0

[28] A. Shah and S. T. Hijazi, "The Determinants of Capital Structure of Stock Exchange-Listed Non-Financial Firms in Pakistan," Pakistan Development Review, Vol. 43, No. 4, 2004, pp. 605-618.

[29] J. Revell, "Inflation and Financial Institutions," Financial Times, London, 1979.

[30] P. Perry, "Do Banks Gain or Lose from Inflation," Journal of Retail Banking, Vol. 14, No. 2, 1992, pp. 25-30.

[31] P. P. Athanasoglou, S. N. Brissimis and M. D. Delis, 
"Bank-Specific, Industry-Specific and Macroeconomic Determinants of Bank Profitability," Bank of Greece Working Paper, No. 25, 2005.

[32] Y. A. Mubarik, "Inflation and Growth: An Estimate of the Threshold Level of Inflation in Pakistan," SBP-Research Bulletin, Vol. 1, No. 1, 2005, pp. 35-44.

[33] M. Gillman, M. Harris and L. Matyas, "Inflation and Growth: Some Theory and Evidence," 10th International Conference on Panel Data, Berlin, July 2002, pp. 1-26.

[34] W. R. J. Alexander, "Inflation and Economic Growth: Evidence from a Growth Equation," Applied Economics, Vol. 29, No. 2, 1997, pp. 233-238. doi: $10.1080 / 000368497327290$

[35] S. Fischer, "The Role of Macroeconomic Factors in Growth," Journal of Monetary Economics, Vol. 32, No. 1, 1993, pp. 485-512.

[36] A. Ghosh and S. Philip, "Inflation, Disinflation, and Growth," IMF Working Paper, Vol. 68, International Monetary Fund, Washington DC, 1998.

[37] K. S. Nell, "Is Low Inflation a Precondition for Faster
Growth? The Case of South Africa," Working Papers in Economics, Department of Economics, Keynes College, University of Kent, Pakistan Economic Survey, 2000.

[38] M. Bruno and W. Easterly, "Inflation and Growth: In Search of Stable Relationship," Federal Reserve Bank of St. Louis Review, Vol. 78, No. 3, 1996, pp. 139-146.

[39] G. Mallik and A. Chowdhury, "Inflation and Economic Growth: Evidence from South Asian Countries," Asian Pacific Development Journal, Vol. 8, No. 1, 2001, pp. 123-135.

[40] M. S. Khan and S. A. Senhadji, "Threshold Effects in the Relationship between Inflation and Growth," IMF Staff Papers, Vol. 48, No. 1, 2001, pp. 1-21.

[41] Balance Sheet Analysis of Joint Stock Companies Listed on the Karachi Stock Exchange, 2001-2006.

[42] Inflation Monitor January 2006 from State Bank of Pakistan.

[43] Inflation Monitor, March 2006 from State Bank of Pakistan. 